\title{
Efektivitas Teknik Relaksasi Melalui Bimbingan Kelompok dalam Mengurangi Rasa Jenuh Belajar Daring
}

\author{
Wa Ode Husniah ${ }^{1 *}$, Maria Ulfa ${ }^{1}$, Winda Andriani ${ }^{1}$ \\ 'Universitas Muhammadiyah Buton, Indonesia \\ *Korespondensi: odehusniah@gmail.com
}

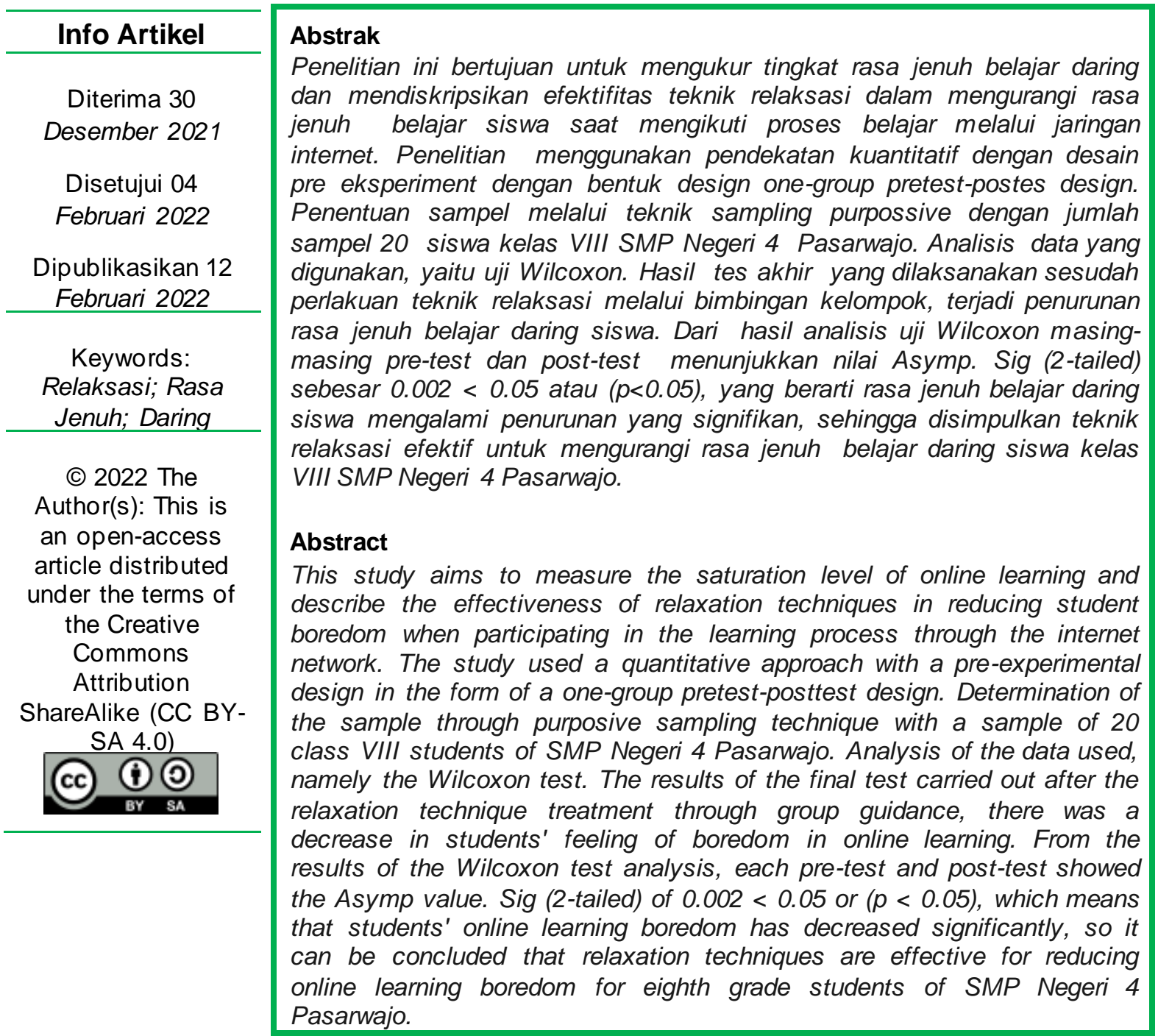

\section{Pendahuluan}

Metode pembelajaran di era pandemi berubah dari proses pembelajaran di kelas secara tatap muka menjadi proses pembelajaran dalam jaringan atau daring. Proses belajar daring menggunakan metode pembelajaran jarak jauh dimana 
semua interaksi dan komunikasi dilakukan melalui aplikasi internet. Sejalan dengan penegasan Menteri Pendidikan dan Kebudayaan bahwa proses belajar mengajar saat pandemi covid-19 harus menyesuaikan dengan keadaan dan situasi yang sedang terjadi, proses pembelajaran yang sebelum pandemi terjadi dilaksanakan di kelas secara tatap muka beralih menjadi pembelajaran dalam jaringan yang dibantu dengan teknologi atau aplikasi-aplikasi pembelajaran jarak jauh (Sekretariat GTK, 2021).

Fenomena ini yang terjadi di SMP Negeri 4 Pasarwajo, Kabupaten Buton dimana tidak semua guru mata pelajaran paham dalam menggunakan aplikasi internet sebagai media pembelajaran. Hal ini berdampak pada kegiatan belajar siswa di rumah sebab tidak semua siswa mampu memahami materi pembelajaran yang disampaikan melalui aplikasi internet. Dalam proses pembelajaran dalam jaringan tersebut siswa merasa beban tugas yang diberikan lebih banyak daripada belajar di kelas secara tatap muka dan tugas tersebut harus diselesaikan tepat waktu. Banyaknya aktivitas dan tugas-tugas pelajaran yang harus dikirim ke email guru yang menggunakan akses internet siswa menyebabkan siswa menjadi lelah dan capek indera mereka dan semangat mereka menurun, merasa bosan, tidak memiliki minat dalam mengikuti proses belajar. (Khusumawati \& Christiana, 2014).

Hakim (2014) menyatakan bahwa kejenuhan belajar merupakan stres yang dirasakan oleh seseorang dalam menerima informasi baru ketika kebosanan dan kelelahan dirasakan amat tinggi hingga menimbulkan kelelahan dan lemas, kurang bersemangat, hingga tidak memiliki gairah dalam melakukan kegiatan belajar. (Mubarok, 2018). Seseorang dalam hal ini siswa saat merasakan kejenuhan belajar akan berpengaruh buruk pada hasil belajarnya. Walaupun durasi belajar yang dipakai sangat panjang tetapi hasil yang dicapai tidak sesuai target dikarenakan kejenuhan dan kelelahan. (Pawicara \& Conilie, 2020)

Muhibbin Syah mengatakan penyebab kejenuhan belajar siswa timbul akibat dari proses belajar siswa yang sudah mencapai taraf maksimal kemampuan jasmaniahnya dalam menerima informasi maupun materi pembelajaran yang mengakibatkan rasa bosan dan letih. (Syah, 2010)

Guru Bimbingan dan Konseling berperan penting dalam menyelesaikan rasa jenuh siswa dalam belajar daring. Salah satu alternatif penyelesaian masalah yang dapat digunakan, tidak membutuhkan waktu yang lama dan mudah dalam menggunakannya adalah pendekatan behavior dengan teknik relaksasi. Teknik relaksasi menurut Cormier dan Cormier merupakan upaya mengajarkan seseorang untuk santai dan tenang, serta membuat seseorang menyadari rasa kaku dan rasa relaks di urat syaraf dari urat syaraf bagian wajah sampai bagian tubuh bawah (kaki) (Sutarjo et al., 2014). Relaksasi merupakan salah satu teknik dalam terapi behavior yang dapat digunakan untuk membangun kepribadian siswa kearah yang baik, menghilangkan bermacam pikiran yang kusut disebabkan ketidakmampuan siswa dalam mengendalikan ego yang dimilikinya, mempermudah siswa mengontrol diri, menyelamatkan jiwa, dan memberikan kesehatan bagi tubuh individu (Khusumawati \& Christiana, 2014)

Adapun pemberian teknik relaksasi dilaksanakan melalui bimbingan kelompok. Bimbingan kelompok merupakan layanan bantuan kepada siswa un tuk memberikan pemahaman dan mengembangkan keterampilan-keterampilan yang 
dibutuhkan sehubungan dengan rasa jenuh belajar siswa dalam jaringan yang dilakukan secara kelompok sebanyak 2 - 10 siswa (Pramudita, 2017)

Hasil penelitian yang dilaksanakan oleh Wicaksono (2017) dengan judul penelitian penerapan bimbingan kelompok teknik diskusi mengurangi kejenuhan belajar siswa kelas VIII SMPN 16 Surabaya menyatakan ada perbedaan skor antara sebelum dan sesudah diberikan bimbingan kelompok dengan teknik diskusi kelompok. Sehingga dapat dikatakan bahwa bimbingan kelompok dengan teknik diskusi kelompok dapat menurunkan kejenuhan belajar siswa kelas VIII SMP Negeri 16 Surabaya.

Pradita Andhi Putri (2021) hasil penelitiannya menyatakan kejenuhan saat pembelajaran online, mayoritas responden berada pada kategori sedang, kategori ini diperoleh sebelum diberikan teknik relaksasi genggam jari. Setelah dilaksanakan teknik relaksasi genggam jari, mayoritas kejenuhan belajar responden berada pada kategori rendah.

Ita Dian Arvita Sari (2020) dalam penelitiannya mereduksi stres dalam belajar dengan menggunakan strategi relaksasi, menyimpulkan bahwa terjadi perbedaan skor stres belajar siswa sebelum dan sesudah diberikan strategi relaksasi. Hal ini dilihat dari skor stres dalam belajar siswa pada siklus I, skor stres belajar siswa berada pada kategori tinggi $(87,5)$ menurun pada kategori sedang (75). Pada siklus II terjadi penurunan lagi menjadi 47,5 (rendah). Dengan demikian strategi relaksasi dapat mereduksi stres dalam belajar siswa kelas XI MIPA 1 SMA Negeri 1 Mantup tahun ajaran 2020/2021.

Berdasarkan uraian di atas penelitian ini bertujuan untuk mengukur tingkat rasa jenuh belajar siswa dalam jaringan (daring) dan mendeskripsikan keefektifan teknik relaksasi melalui bimbingan kelompok dalam mengurangi rasa jenuh belajar daring siswa.

\section{Metode Penelitian}

Jenis penelitian yang digunakan adalah penelitian kuantitatif. Di mana subyek penelitian diberikan perlakuan (treatment) kemudian diukur pengaruh dari teknik relaksasi yang digunakan pada subyek (Arikunto, 2010). Penelitian ini dilaksanaan di SMP Negeri 4 Pasarwajo, Kecamatan Pasarwajo, Kabupaten Buton.

Subyek dalam penelitian ini berjumlah 20 orang siswa kelas VIII SMP Negeri 4 Pasarwajo. Teknik sampel yang digunakan adalah teknik nonprobability sampling, yaitu purposive sampling, yaitu cara untuk menentukan sampel dengan pertimbangan spesifik. (Sugiyono, 2012).

Metode pre eksperimental merupakan metode penelitian yang digunakan dalam penelitian ini dengan rancangan penelitiannya adalah one-group pretestpostest design. Secara rinci dapat dilihat pada tabel berikut :

Tabel 1. Desain Rancangan Penelitian Pre Eksperimental.

\begin{tabular}{ccc}
\hline Pre-test & Perlakuan & Post-test \\
\hline $\mathrm{O}_{1}$ & $\mathrm{X}$ & $\mathrm{O}_{2}$ \\
\hline
\end{tabular}

Keterangan :

O1 : tes pertama (pre-test) dilaksanakan sebelum pemberian perlakuan teknik relaksasi melalui bimbingan kelompok. 
$X$ : pelaksanaan teknik relaksasi melalui bimbingan kelompok

$\mathrm{O}_{2}$ : Tes terakhir (post-test) dilaksanakan sesudah pelaksanaan teknik relaksasi melalui bimbingan kelompok

Instrumen penelitian yang digunakan, yaitu instrument skala kejenuhan belajar daring siswa sebagai teknik pengumpulan data yang berbentuk kuesioner. Metode analisis data yang digunakan adalah uji Wilcoxon.

\section{Hasil}

\subsection{Kategorisasi Tingkat Rasa Jenuh Belajar Daring Siswa Sebelum Pemberian Perlakuan}

Kriteria kategorisasi yang digunakan yaitu tinggi, sedang dan rendah, berdasarkan pada deviasi baku dan mean hipotik. (Saifuddin Azwar, 2012). Kategorisasi yang pergunakan, yaitu kategorisasi jenjang sesuai distribusi normal.

Untuk mengukur tingkat rasa jenuh belajar daring siswa SMP Negeri 4 Pasarwajo sebelum dilaksanakan teknik relaksasi melalui bimbingan kelompok dilakukan pre test dengan menggunakan skala rasa jenuh belajar daring. Hasil pre test sebagai berikut.

Tabel 2. Pre test Kejenuhan belajar daring siswa

\begin{tabular}{llll}
\hline Kategori & Kriteria & F & $(\%)$ \\
\hline Rendah & $\mathrm{X}<60$ & 0 & 0 \\
\hline Sedang & $60 \leq \mathrm{X}<90$ & 14 & 70 \\
\hline Tinggi & $90 \leq \mathrm{X}$ & 6 & 30 \\
\hline
\end{tabular}

Merujuk tabel 3 di atas siswa kelas VIII SMP Negeri 4 Pasarwajo berada pada kategori tinggi sebanyak 6 orang dengan persentase 30\%, kategori sedang 14 orang dengan persentase $70 \%$ dan kategori rendah persentase $0 \%$. Secara umum tingkat kejenuhan belajar daring siswa kelas VIII SMP Negeri 4 Pasarwajo yaitu ada pada kategori tinggi.

Selanjutnya kategorisasi tingkat kejenuhan belajar daring siswa SMP Negeri 4 Pasarwajo berdasarkan indikator dari aspek kejenuhan belajar daring sebagai berikut.

Tabel 3. Kategorisasi berdasarkan indikator kejenuhan belajar daring siswa

\begin{tabular}{|c|c|c|c|c|}
\hline No & Indikator & $\mathbf{F}$ & $\%$ & Kategorisasi \\
\hline \multirow{3}{*}{1} & \multirow{3}{*}{ Kelelahan Emosi } & 4 & 20 & Rendah \\
\hline & & 7 & 35 & Sedang \\
\hline & & 9 & 45 & Tinggi \\
\hline \multirow{3}{*}{2} & \multirow{3}{*}{ Kelelahan Fisik } & 5 & 25 & Rendah \\
\hline & & 6 & 30 & Sedang \\
\hline & & 9 & 45 & Tinggi \\
\hline \multirow{3}{*}{3} & \multirow{3}{*}{ Kelelahan Kognitif } & 5 & 25 & Rendah \\
\hline & & 5 & 25 & Sedang \\
\hline & & 10 & 50 & Tinggi \\
\hline \multirow{3}{*}{4} & \multirow{3}{*}{ Kehilangan motivasi } & 4 & 20 & Rendah \\
\hline & & 7 & 35 & Sedang \\
\hline & & 9 & 45 & Tinggi \\
\hline
\end{tabular}


Merujuk tabel di atas, masing-masing indikator memiliki persentase kategori yang berbeda-beda dan yang mendominasi adalah kategori tinggi. Indikator kelelahan kognitif yang paling dominasi kejenuhan belajar siswa kelas VIII SMP Negeri 4 Pasarwajo. Hal ini terjadi disebabkan pembelajaran sekarang ini diukur berdasarkan pencapaian secara kognitif. Untuk itu, siswa harus terus belajar di bawah tekanan untuk mencapai nilai bagus (Ningsih, 2016)

\subsection{Kategorisasi Tingkat Rasa Jenuh Belajar Daring Siswa Sesudah Pemberian Perlakuan}

Setelah pelaksanaan teknik relaksasi melalui bimbingan kelompok dilakukan post test dengan menggunakan skala rasa jenuh belajar daring. Hasil dari pengukuran post test sebagai berikut.

Tabel 4. Post test kejenuhan belajar daring siswa

\begin{tabular}{cccc}
\hline Kategori & Kriteria & F & $(\%)$ \\
\hline Rendah & $\mathrm{X}<60$ & 17 & 85 \\
\hline Sedang & $60 \leq \mathrm{X}<90$ & 3 & 15 \\
\hline Tinggi & $90 \leq \mathrm{X}$ & 0 & 0 \\
\hline
\end{tabular}

Tabel 5 memperlihatkan, tingkat rasa jenuh belajar daring siswa kelas VII SMP Negeri 4 Pasarwajo mengalami penurunan secara signifikan yaitu seban yak 17 siswa berkedudukan pada kategori rendah dengan persentase 85\%, kategori sedang sebanyak 3 siswa dengan presentasi 15\% dan kategori tinggi dengan persentasei $0 \%$.

Kategorisasi tingkat kejenuhan belajar daring siswa SMP Negeri 4 Pasarwajo berdasarkan indikator dari aspek kejenuhan belajar daring sebagai berikut.

Tabel 5 Kategorisasi berdasarkan indikator kejenuhan belajar daring

\begin{tabular}{|c|c|c|c|c|}
\hline No & Indikator & $\mathbf{F}$ & $\%$ & Kategorisasi \\
\hline \multirow{2}{*}{1} & \multirow{2}{*}{ Kelelahan Emosi } & 13 & 65 & Rendah \\
\hline & & 7 & 35 & Sedang \\
\hline \multirow{2}{*}{2} & \multirow{2}{*}{ Kelelahan Fisik } & 15 & 75 & Rendah \\
\hline & & 5 & 25 & Sedang \\
\hline \multirow{2}{*}{3} & \multirow{2}{*}{ Kelelahan Kognitif } & 17 & 85 & Rendah \\
\hline & & 3 & 15 & Sedang \\
\hline \multirow{2}{*}{4} & \multirow{2}{*}{ Kehilangan Motivasi } & 18 & 90 & Rendah \\
\hline & & 2 & 10 & Sedang \\
\hline
\end{tabular}

Tabel 5 menunjukkan, setiap indikator pada skala rasa jenuh belajar daring mengalami penurunan skor rasa jenuh belajar daring dari sebelum diberikan teknik relaksasi (pre test) hingga diberikannya teknik relaksasi melalui bimbingan kelompok (post test).

Berikuthasil analisis uji Wilcoxon dan tes statistik

Tabel6. Test Statistics wilcoxon

\begin{tabular}{cc}
\hline & Pre Test - Post Test \\
\hline$Z$ & $-3.925^{\mathrm{a}}$ \\
\hline Asymp. Sig. (2-tailed) & .000 \\
\hline
\end{tabular}

Sumber SPSS 21 
Merujuk hasil uji Wilcoxon signed Rank Test pada tabel di atas, menunjukkan signifikan sebesar $0,000<0,05$ sehingga dapat dikatakan memiliki perbedaan yang signifikan secara statistik pada skala rasa jenuh belajar daring saat dilaksanakan pre-test dan post test. Hipotesis terbukti bahwa teknik relaksasi melalui bimbingan kelompok efektif mengurangi rasa jenuh belajar daring siswa kelas VIII SMP Negeri 4 Pasarwajo. Menurut Hakim (2014) bahwa kejenuhan belajar dapat diatasi dengan melakukan relaksasi dan dapat membantu menenangkan jiwa atau rasa jenuh yang dialami siswa (Sutarjo et al., 2014)

\section{Pembahasan}

Dari hasil penelitian di atas menunjukkan bahwa siswa memiliki tingkat rasa jenuh yang tinggi dalam mengikuti pembelajaran daring. Rasa jenuh balajar daring ini karena siswa sulit dalam mencerna materi pembelajaran dari guru disebabkan metode pembelajaran guru yang monoton, beban tugas yang diberikan sangat banyak, belajar sendiri tanpa teman belajar dan berkurangnya konsentrasi diakibatkan terlalu lama dalam menatap layar handphone atau laptop serta keterbatasan kuota internet (Ningsih, 2020).

Hal senada dikemukakan oleh Kurnia (2020), rasa jenuh dan kebosanan dalam belajar yang dihadapi siswa dikarenakan ketidakberdayaan siswa dalam memahami atau mencerna materi pelajaran yang disampaikan oleh guru melalui platform pembelajaran online dan tidak ada yang dapat membantu mereka jika mengalami hambatan dalam memahami pelajaran hingga timbullah rasa bosan dan malas dalam belajar. Menurut Syah (Pawicara \& Conilie, 2020) menyatakan penyebab timbulnya rasa jenuh dalam belajar pada diri seseorang adalah adan ya rasa tidak berdaya setelah melakukan aktivitas kerja yang berat, informasi baru yang diterima oleh memori otak cukup banyak.

Proses pembelajaran yang berkepanjangan yang dialami siswa serta tekanan-tekanan baik dalam diri sendiri maupun lingkungan untuk meraih prestasi akademik yang tinggi diluar batas kemampuan jasmaniahnya , akhirnya siswa merasa letih fisik dan emosi. Selain itu kegiatan menerima informasi berupa materi pelajaran yang dilakukan satu arah dan lingkungan yang tidak kondusif untuk belajar daring mengakibatkan rasa jenuh, bosan dan malas dalam belajar.

Penanganan yang diberikan kepada siswa yang mengalami rasa jenuh dalam mengikuti pembelajaran daring yaitu dengan memberikan teknik relaksasi melalui bimbingan kelompok yang dilakukan dengan sebanyak 7 kali pertemuan. Teknik relaksasi adalah suatu tindakan pemberian bantuan kepada siswa agar memiliki kesadaran diri dengan cara memberikan perlakuan relaksasi. Maka masing-masing siswa memiliki tanggung jawab dan kesadaran diri akan dirinya sendiri. Relaksasi adalah kegiatan dan gerakan diri untuk melatih keseimbangan dan keyakinan diri untuk memaksimalkan daya tahan tubuh hingga seseorang merasakan ketenangan, kondisi emosi yang stabil dan tidak merasa tegang. (Sutarjo et al., 2014). Teknik relaksasi merupakan satu dari beberapa teknik terapi pemberian intruksi pada seseorang untuk fokus atau konsentrasi menarik dan menghembuskan nafas dengan menutup mata. juga melalkukan gerakan tangan, otot lengan, bahu, leher, dan kaki. Mengendornya otot-oto badan yang kaku menjadi santai (rileks) akan menimbulkan perasaan nyaman dan tenang.

Teknik relaksasi melalui bimbingan kelompok diberikan pada pertemuan keempat sampai ketujuh. Relaksasi yang dilakukan saat pertemuan keempat 
dimulai dengan gerakan tangan, leher, bahu dan kaki. Pada pertemuan kelima melakukan gerakan muka dan perenggangan otot yakni berdiri dan berjalan sambil menghirup udara dan menghembuskan. Pertemuan keenam dilanjutkan melakukan gerakan dada, paha dan perut. Terakhir pertemuan ketujuh siswa melakukan gerakan secara keseluruhan dan menghilangkan pikiran-pikiran negative tentang dirinya dan pembelajaran.

Kegiatan teknik relaksasi melalui bimbingan kelompok dilaksanakan dengan melakukan kegiatan relaksasi secara bersama-sama dan bertukar pikiran antar siswa lain dalam kelompok mengenai cara mengatasi rasa jenuh dalam belajar melalui online atau platform pembelajaran. Dengan berdiskusi siswa mendapatkan informasi dan cara mengatasi kejenuhan dan keletihan dalam belajar melalui online secara bersama dengan teman sebayanya. Menurut Hasibuan \& Moedjiono menyatakan bahwa diskusi adalah suatu cara membimbing lewat kelompok, dengan memberi kesempatan pada anggota kelompok untuk memberikan masukan dan saran atas permasalahan yang dialami. Dalam diskusi semua aggota kelompok terlibat secara aktif menyelesaikan masalah secara bersamasama baik memberikan ide-ide, saran maupun saling menanggapi antar anggota kelompok (Wicaksono et al., n.d.)

Dari hasil penelitian, setelah pelaksanaan teknik relaksasi melalui bimbingan kelompok, rasa jenuh dalam belajar daring siswa mengalami penurunan yang signifikan. Akhirnya dapat dikatakan bahwa teknik relaksasi melalui bimbingan kelompok efektif mengurangi rasa jenuh dalam belajar daring siswa.

\section{Kesimpulan}

Proses pembelajaran dalam jaringan internet (daring) dengan menggunakan program aplikasi internet yang ada menyebabkan para siswa khususnya siswa kelas VIII SMP Negeri 4 Pasarwajo mengalami rasa jenuh belajar yang sangat tinggi. Hal ini berdasarkan hasil pengukuran pre test, 14 siswa (70\%) berada pada kategori sedang dan 6 siswa (30\%) berada pada kategori tinggi. Penanganan yang diberikan kepada siswa, yaitu teknik relaksasi yang dilaksanakan pada pertemu an keempat dan ketujuh. Kegiatan teknik relaksasi melalui bimbingan kelompok dilaksanakan dengan bertukar pikiran, antar siswa lain dalam kelompok men genai cara mengatasi rasa jenuh dalam belajar. Setelah diberikan penanganan dengan teknik relaksasi melalui bimbingan kelompok menunjukkan perubahan yang signifikan penurunan tingkat rasa jenuh dalam belajar daring siswa berdasarkan hasil post test, $17(85 \%)$ siswa berada pada kategori rendah dan $3(15 \%)$ siswa berada pada kategori sedang dan uji Wilcoxon dengan signifikansi sebesar $0,000<$ 0,05 . Artinya Teknik relaksasi melalui Bimbingan kelompok efektif mengurangi rasa jenuh belajar daring siswa kelas VIII SMP Negeri 4 Pasarwajo.

\section{Daftar Pustaka}

Arikunto. (2010). Prosedur Penelitian Suatu Praktek. Rineka Cipta.

Khusumawati, Z. E., \& Christiana, E. (2014). Penerapan Kombinasi Antara Teknik Relaksasi Dan Self-Instruction Untuk Mengurangi Kejenuhan Belajar Siswa Kelas XI IPA 2 SMAN 22 Surabaya. Bk Unesa, 5(1), 1-10.

KURNIA, D. (2020). Dinamika Gejala Kejenuhan Belajar Siswa Pada Proses Belajar Online Faktor Faktor Yang Melatarbelakangi Dan Implikasinya Pada Layanan Bimbingan Keluarga. Teaching: Jurnal Inovasi Keguruan Dan IImu 
Pendidikan, 1(1), 1-10.

Mubarok, mukhamad ilham. (2018). Upaya Menurunkan Kejenuhan Belajar Melalui Bimbingan Kelompok Teknik Games Pada Siswa Kelas Xi Akuntansi Smk the Use of Group Counselling Using Games Technique To Reduce Study. Jurnal Riset Mahasiswa Bimbingan Dan Konseling, 4(3), 143-154.

Mulinda, R., \& Conia, P. D. D. (2020). Efektivitas Bimbingan Kelompok Dengan Teknik Sosiodrama Untuk Meningkatkan Empati Siswa. Jurnal Penelitian Bimbingan dan Konseling, 5(2).

Ningsih, F. (2016). Efektifitas Teknik Relaksasi Untuk Mengurangi Kejenuhan. EJournal Bimbingan Dan Konseling Edisi 7 Tahun Ke-5, 7(5), 50-59.

Ningsih, S. (2020). Persepsi Mahasiswa Terhadap Pembelajaran Daring Pada Masa Pandemi Covid-19. JINOTEP (Jurnal Inovasi Dan Teknologi Pembelajaran): Kajian Dan Riset Dalam Teknologi Pembelajaran, 7(2), 124132.

Pawicara, R., \& Conilie, M. (2020). Analisis Pembelajaran Daring Terhadap Kejenuhan Belajar Mahasiswa Tadris Biologi lain Jember di Tengah Pandemi Covid-19. ALVEOLI: Jurnal Pendidikan Biologi, 1(1), 29-38.

Pradita Andhi Putri, D. (2021). Pengaruh Relaksasi Genggam Jari Terhadap Kejenuhan Saat Pembelajaran Online Dimasa Pademi Covid-19 Pada Siswa Di SMK 1 NAWANGAN (Doctoral dissertation, Universitas Kusuma Husada Surakarta).

Pramudita, B. (2017). Development of Self Empowerment Career Design (SECD) Booklet for 10th Grade Fashion Students in SMK Daruttaqwa Gresik. Universitas Negeri Surabaya Journal, 7.

Saifuddin Azwar. (2012). Penyusunan Skala Psikologi (2nd ed.). Pustaka Pelajar.

Sari, I. D. A. (2020). Mereduksi Stres Dalam Belajar Dengan Menggunakan Strategi Relaksasi. Nusantara of Research: Jurnal Hasil-hasil Penelitian Universitas Nusantara PGRI Kediri, 7(2), 79-85

Sekretariat GTK. (2021). Kebijakan Kemendikbud di Masa Pandemi. Direktorat Jenderal Guru Dan Tenaga Kependidikan, Kementerian Pendidikan, Kebudayaan, Riset, Dan Teknologi, Republik Indonesia

Sutarjo, Ip. E., Arum, D. W., \& Suarni, N. K. (2014). Efektivitas Teori Behavioral Teknik Relaksasi dan Brain Gym Untuk Menurunkan Burnout Belajar Pada Siswa Kelas VIII SMP Laboratorium UNDIKSHA SINGARAJA Tahun Pelajaran 2013/2014. E-Journal Undiksa Jurusan Bimbingan Konseling, 2(1).

Syah, M. (2010). Psikologi Belajar. PT Raja Grafindo Persada.

Wicaksono, M. T., Pendidikan, F. I., Surabaya, U. N., Nuryono, W., Kelompok, T. D., \& Belajar, K. (n.d.). Application Of Group Guidance With Technique Discussions To Reduce Boredom Learning Of 8 Th Grade Students In Smpn 16. 